Journal of Agricultural Sciences
(Tarim Bilimleri Dergisi)

\title{
Determination of Melatonin Differences between Day and Night Milk in Dairy Cattle
}

\author{
Özcan ŞAHIIN ${ }^{a}\left(\mathbb{D}\right.$, Fikret AKYÜREK ${ }^{b}(\mathbb{D})$, Saim BOZTEPE ${ }^{a}(\mathbb{D})$, \\ İbrahim AYTEKİN ${ }^{\mathrm{a}}$ (D), İsmail KESKİNa* iD \\ ${ }^{a}$ Department of Animal Science, Faculty of Agriculture, University of Selcuk, Konya, TURKEY

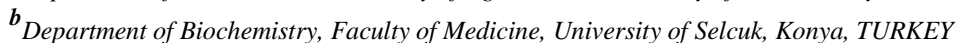

\section{ARTICLE INFO}

Research Article

Corresponding Author: İsmail KESKİN, E-mail: ikeskin@selcuk.edu.tr

Received: 11 February 2020 / Revised / 19 May 2020 / Accepted: 04 June 2020 / Online: 04 December 2021

\section{ABSTRACT}

The aim of this study was to determine the difference between melatonin hormone in night milk and melatonin concentration in day milk of Holstein cows. In this study, daytime milk obtained from 40 heads Holstein cows in the first lactation raised in a private dairy cattle farm in Karapınar district of Konya state province in Turkey and night milk samples taken from the same cows that were kept in darkness for one week were used. The milk samples were collected from day and night milking in order to determine the melatonin concentration with the help of Bovine Melatonin (MLT) Elisa Kit. In this study, melatonin concentration in day time and night time milk were determined as respectively $103.70 \pm 6.61 \mathrm{pg} \mathrm{mL}^{-1}$ and $163.13 \pm 8.96 \mathrm{pg} \mathrm{mL}^{-1}$. The difference between melatonin levels of day and night milk was statistically significant $(\mathrm{P}<0.01)$. Since significant difference occurred between melatonin concentration between day and night milk at the end of the study, it can be stated that night milk can be used for medical purposes that is used cure of some illnesses and producers can be provided with a new production source.

Keywords: Holstein, Melatonin, Night milk, Day-time milk, Dairy cattle

(C) Ankara University, Faculty of Agriculture

\section{Introduction}

Melatonin is a hormone secreted from the gland called pineal or epiphysis located at the base of the brain, which weighs 100 $180 \mathrm{mg}$ in mature humans and a tiny pea-sized gland. Melatonin in the blood is found between 60-70\% depending on the albumin (Ölmez et al. 2000; Atasoy \& Erbaş 2017). Melatonin secretion is not restricted to mammals but is also produced in nonmammalian vertebrates, in some invertebrates, and in many plants, with the same molecular structure. The synthesis of melatonin is strictly controlled by lighting conditions and shows a clear circadian rhythm with low values during the daytime and significant increase at night (Karasek \& Winczyk 2006; Srinivasan et al. 2011). This hormone secret during sleep at night, is intensely secreted, especially between 23 and 05 hours. For this intense secretion to occur, the environment must be dark (Jainudeen 2000; Ölmez et al. 2000; Karasek \& Winczyk 2006; Balch 2010; Atasoy \& Erbaş 2017). Pineal gland is present in all vertebrates. Mammalian pineal is derived from photo-receptor cells capable of synthesizing melatonin (Gupta \& Spessert 2007). This gland consists of specialized epithelial cells called pinealocytes. In mammals, the pineal gland loses its ability to synthesize melatonin when exposed to direct light. Melatonin synthesis is at the lowest level during the day (light phase) and at the highest level at night (dark phase) (Boztepe 2019).

Melatonin is synthesized from tryptophan amino acid in all vertebrates. It is first converted to 5-hydroxy tryptophan by the tryptophan hydroxylase enzyme and then to 5-hydroxytryptamine, that is, serotonin, by the aromatic L-amino acid decarboxylase enzyme. Serotonin is converted to the N-acetylserotonin form by the AA-NAT (Arylalkylamine-N-acetyltransferase) enzyme. Finally, $\mathrm{N}$-acetylserotonin is converted to $\mathrm{N}$-acetylmethoxideriptamine, melatonin, via the HIOMT (hydroxyindole-Omethyltransferase) enzyme. While AA-NAT limits melatonin secretion with very low activity during the day, it reaches high activity at night. As a result, the rate of conversion of serotonin to melatonin is minimal as it leads to the accumulation of serotonin in pinealocytes during daytime. AA-NAT activity increases at the onset of darkness, which regulates the rate of melatonin synthesis. It causes norepinephrine (NE) secretion to increase from the end of the postganglionic sympathetic nerve fibers present in the pineal gland. NE plays a role as a second means on pinealocytes via membrane-bound adrenergic receptors and cAMP, leading to an increase in melatonin synthesis and secretion (Gupta \& Spessert 2007). According to Özçelik et al. (2013), in human the secretion of melatonin hormone depends on the sensitivity of pinealocyte cells to light. With this sensitivity, light inhibition is eliminated in the dark, and melatonin secretion is increased again. Especially between 23:00 and 05:00 at night, 
melatonin secretion peaks and its concentration in the blood increases 3-10 times. In humans, the release of melatonin starts to increase in the evening at 21.00-22.00 hours and reaches the highest level at 02.00-04.00 hours. It starts to decrease at 05.0007.00 in the morning and drops to basal levels after 07.00 . While the blood concentration of melatonin is approximately $0-20 \mathrm{v}$ during the day, it increases to 50-200 $\mathrm{pg} \mathrm{mL}^{-1}$ during the night. An average of $30 \mathrm{mg}$ melatonin is synthesized overnight. Singh and Rao (2016) reported that the melatonin exchange interval in low-density in human, cow and goat milk was 5-25 pg mL ${ }^{-1}$. Romanini et al. (2019) found the highest concentration of melatonin in individual cow's milk as $41.94 \mathrm{pg} \mathrm{mL}^{-1}$. They reported that there were seasonal changes and that the highest melatonin concentration was reached at night hours in winter.

Melatonin is a very powerful antioxidant, it is stronger than vitamin C, E or beta carotene, and it prevents harmful oxidation. In this way, it can reduce the risk of hypertension, heart attack and some types of cancer. It has also been stated that it regulates the immune system, prevents memory loss, vascular congestion and paralysis, and can be useful in the treatment of Alzheimer's and cancer (Yazıcı \& Köse 2004; Hardeland et al. 2011; Özçelik et al. 2013; Salt et al. 2017). In addition, there is no toxic level of melatonin consumption (Balch 2010). In case of covering long distances in a short time, biological dysfunctions occur in the body, and the biological balance is disrupted due to the changes of the biological clock. According to some sources, melatonin plays a role in the regulation of biological clock (Liu \& Borjigin 2006). In fact, the arrangement of the biological clock provides regular secretion of melatonin in the body and provides protective and therapeutic functions. Jimenez et al. (2009) have reported that goat somatic cell count (SCC) is a very important quality indicator, and it is related to the function of the immune cells in the breast and oxidative metabolism. Researchers have stated that melatonin plays a positive role in oxidative metabolism. The same study group divided 60 Verata goats into two groups in order to demonstrate the effects of melatonin implant reduction on SCC in dairy goats. The first group was the melatonin implanted and the other was the non-implanted control group. All animals were followed bacteriologically during lactation and evaluated for clinical mastitis. Blood and milk samples were taken three days after birth and four times at monthly intervals. At the end of the experiment, the milk composition did not change and SCC decreased significantly in the middle of lactation in the implant group compared to the control group.

Because of these benefits of melatonin, determination of natural resources is very important. In animal products milk etc, melatonin is more abundant in night milk than in day-time milk. There have been some studies on this subject abroad (Valtonen et al. 2005; Asher et al. 2015; Romanini et al. 2019) but the studies on this issue are quite insufficient in our country. This study was conducted to determine the level of melatonin in milk obtained from day and night milking of Holstein cows, and the production status of a natural source of melatonin.

\section{Material and Methods}

\subsection{Material}

The animal material of the study consisted of the milk samples obtained from the first lactating Holstein cows which were raised farm in Karapınar district of Konya province in Turkey. Milk samples were collected from the same cows as day milk (evening milking) at the beginning of the study and night milk after one week darkening application at nights. Cows are milked three times a day at 07.00 in the morning, at 16.00 in the evening and at 01.00 at night.

\subsection{Method}

The samples to be analysed were obtained through milking the milk produced during the day by 40 heads of Holstein cows in the first lactation.

The cows were kept in a completely darkened barn for a week. Because of milking program differenced the cows is being probably mastitis, since the management of the enterprise could not be interfered, the animals were exposed to light in the milking house for their night milking.

Milk samples were homogenously taken (from onset to end of milking) carefully taken into $50 \mathrm{~mL}$ tubes to represent the total milk with the help of milk sampling apparatus which can be mounted to the milking system. The milk samples were transferred to the laboratory in cold chain, and dark environment being homogenized and filled into $8 \mathrm{~mL}$ polypropylene tubes.

In the laboratory, the samples were centrifuged twice at $4500 \mathrm{rpm}$ for 15 minutes. After each centrifugation, the fat layer accumulated in the upper part was removed and the milk samples completely separated from the fat were kept at $-80{ }^{\circ} \mathrm{C}$ until study day. On the study day, the samples were first thawed to $-20{ }^{\circ} \mathrm{C}$, then to $+4{ }^{\circ} \mathrm{C}$ and finally at room temperature. After thawing, homogenization was achieved through vortexing. Homogenized samples were prepared using the MYBIOSOURCE brand Bovine Melatonin (MLT) ELISA Kit (Competitive ELISA) (MBS743340, Mybiosource, California, USA) and in accordance with the kit procedure, using the Rayto RT-2600 Microplate Washer (India) washer and BMG LABTECH (EnzymeLinked Immuno Sorbent Assay (ELISA) scanner Melatonin levels were determined in pg $\mathrm{mL}^{-1}$. The quantitation limits of the melatonin kit used were between 0-1000 $\mathrm{pg} \mathrm{mL}^{-1}$ and no dilution was applied to the samples. 
Differences between melatonin levels in day and night milk were determined by pairing t-test in order to prevent dependence since the samples were taken from the same animals before and after darkening (Kesici \& Kocabaş 2007). Statistical analyses were performed with the help of MINITAB statistical package program (Minitab 2010).

\section{Results and Discussion}

Melatonin levels were determined with ELISA method from the samples of the daytime milk taken at the beginning of the study and the milk samples obtained only in the evening without any additional application (feeding, lighting, etc.) from the same cows in the barn prevented from receiving light for a week.

At the end of the study, the rate of melatonin in day milk was $103.70 \mathrm{pg} \mathrm{mL}^{-1}$ and in night milk it was $163.13 \mathrm{pg} \mathrm{mL}^{-1}(\mathrm{Table}$ 1). The difference between melatonin levels of day and night milk was statistically significant $(\mathrm{P}<0.01)$.

Table 1- Melatonin levels and standard errors in day and night milk

\begin{tabular}{lcrrc}
\hline Samples & $n$ & $\overline{\boldsymbol{X}} \pm \boldsymbol{S}_{\overline{\boldsymbol{X}}}$ & \multicolumn{1}{c}{ Min } & Max \\
\hline Day Milk $\left(\mathrm{pg} \mathrm{mL} \mathrm{mL}^{-1}\right)$ & 40 & $103.70 \pm 6.61$ & 28.76 & 213.68 \\
Night Milk $\left(\mathrm{pg} \mathrm{mL} \mathrm{mL}^{-1}\right)$ & 40 & $163.13 \pm 8.96$ & 64.58 & 322.08 \\
Difference $(\mathrm{pg} \mathrm{mL}-1)$ & 40 & $59.43 \pm 12.81$ & 1.26 & 293.32 \\
\hline
\end{tabular}

The difference of between day and night milk was $59.43 \mathrm{pg} \mathrm{mL}^{-1}$. (Table 1, Figure 1). This difference is important only in determining the difference between day and night milk without any application. This difference is also above the highest melatonin value of $41.49 \mathrm{pg} \mathrm{mL}^{-1}$ in the milk produced overnight. Asher et al. (2015) detected melatonin levels in milk in darkness at night and in limited lighting conditions at night. Melatonin level of the night milk in the dark is around $30 \mathrm{pg}^{\mathrm{mL}} \mathrm{m}^{-1}$, while in the group with limited illumination it is between $15-20 \mathrm{pg} \mathrm{mL}^{-1}$. The difference between melatonin levels of daytime milk and animals kept in total darkness and cows with limited illumination at night was also significant. Melatonin detected in daytime milk of animals kept in the dark at night decreased with limited illumination. That is, any lighting or light leads to a decrease in the level of melatonin.

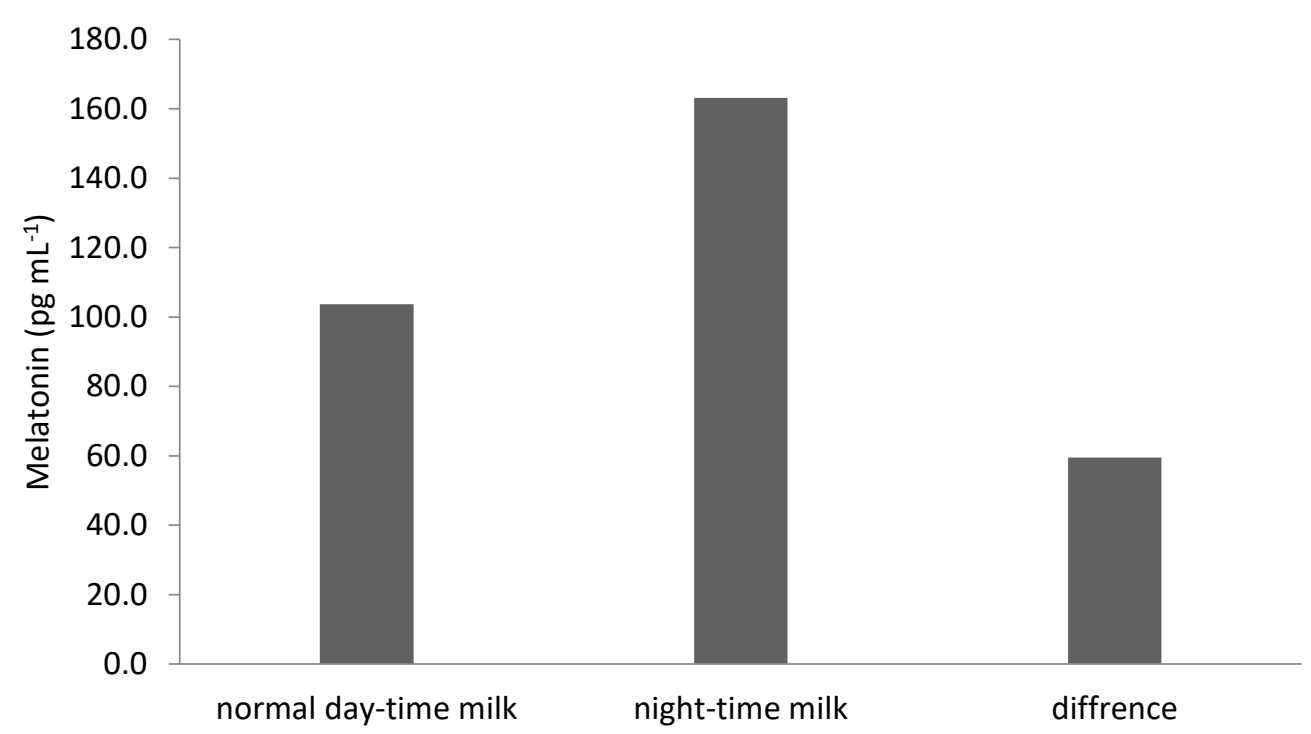

Figure 1- Melatonin levels in day and night milk

Asher et al. (2015) also studied the effects of the seasons on melatonin levels. Differences in melatonin levels of daytime milk and night milk in dark or limited lighting conditions between winter and summer months were found statistically significant. While melatonin levels under darkened conditions were around $22 \mathrm{pg} \mathrm{mL}^{-1}$ in low yield animals, it was $16 \mathrm{pg} \mathrm{mL}^{-1}$ in high yield animals under the same conditions in winter. The same researchers investigated differences between melatonin levels in cow milk, UHT (Ultra High Temperature) milk and tank milk. While there was no statistically significant difference between cow milk and UHT milk in winter, the difference between tank milk was significant. At the same time, the difference between UHT milk and tank milk is statistically insignificant.

In this study, melatonin levels for both day and night milk were found higher than those reported in the literature (Asher et al. 2015; Romanini et al. 2019). The possible cause of this difference may be attributed to the different kits used to determine melatonin level and the differences in seasons. That is, the reference range for melatonin levels in the Elisa kit (MYBIOSOURCE brand Bovine Melatonin (MLT) ELISA Kit (Competitive ELISA) (Catalog Number: MBS743340)) catalog used in this study is between 0 and 1000 while this reference ranges from 0 to 50 in the catalogs of different companies. 


\section{Conclusions}

Valtonen et al. (2005) reported that even the lowest dose of melatonin, $0.1 \mathrm{mg}$, was 10 times greater than total melatonin secreted at night. So, it is impossible to meet this amount by consuming melatonin-rich milk. Accordingly, at least half a liter of 'night milk' produced from cows should be consumed by adults, especially children and the elderly as a supplement to patients' melatonin secretion basing on the reports of Valtonen et al. (2005). When this is realized, it is likely that complaints about many diseases or disorders on which melatonin is known to be effective will be reduced. As demonstrated in some studies, melatonin has a protective effect. Therefore, consuming this milk, at least for protection, will have important health-related contributions. Although the level of melatonin in milk is far from meeting the needs of people, meeting the milk needs from night milk can be helpful in reducing many melatonin-induced diseases or symptoms. In the study on this issue, Konturek et al. (2007) reported that plasma melatonin levels decreased with age. It is a known fact that the complaints about illness and health increase at the age of 50s-55s normally. It is also known that these complaints increase in later ages. That is, plasma melatonin level decreases with age and when these known facts are evaluated together, it can be concluded that the event is related to melatonin. Thus, plasma melatonin levels in the 21-25 age range reach up to $80 \mathrm{pg} \mathrm{mL}^{-1}$, while this value is almost halved in the 51-55 age range. According to the results of the present study, an average of $163 \mathrm{pg} \mathrm{mL}^{-1}$ melatonin was detected in the milk obtained from cows overnight. Considering that a glass is $200 \mathrm{~mL}, 163 \times 200=32600 \mathrm{pg}$ of melatonin is consumed. At night, one glass of milk at night can contribute to increase the decreased level of melatonin in the 51-55 age range to reach the 21-25 age range and decrease the possible complaints.

Melatonin has a vital role in humans, animals and plants and is essential for a healthy life, and even the resources rich in melatonin should be evaluated for a healthy and happy life. For example, in Finland (Valtonen et al. 2005) and Germany (Mullins 2010), melatonin-rich milk produced from cattle under the name of "night time milk" has been commercially produced. In this regard, Valtonen et al. (2005) reported that melatonin secretion decreased with age and that they used the night milk called "night time milk" as the material for the elimination of sleep disorders in elderly people, and they accomplished positive results when the patients were given approximately 0.61 liters day ${ }^{-1}$. Bae et al. (2016) compared the effects of consuming normal milk containing $100 \mathrm{pg}$ melatonin and $47.5 \mathrm{mg}$ tryptophan amino acid with a glass of night milk containing $1000 \mathrm{pg}$ melatonin and $58.24 \mathrm{mg}$ tryptophan amino acid. As a result, a glass of overnight milk containing $1000 \mathrm{pg}$ of melatonin increased sleep comfort and decreased insomnia throughout the day.

Regarding this melatonin-rich (approximately 67\% richer), which can be called "night time milk" or night milk; (1) new studies related to production should be conducted, (2) the time when the levels of melatonin are highest in milk at night should be determined, (3) which light sources are more suitable for the production of night milk with melatonin should be ascertained, (4) how tryptophan contribution in feed will contribute to melatonin production in "night milk" should be established as tryptophan amino acid is the source of melatonin, and (5) the effects of "night milk" on patients should be investigated, and also (6) this melatonin-rich milk is marketed as "night time milk" in some countries. In Turkey, these studies should be carried out and melatonin-rich milk should be more produced in dairy cattle farms and it is important that this product is delivered to the consumers.

\section{Acknowledgements}

This research was supported by a grant from The Scientific Research Project Office of Selcuk University, Turkey (Project No: 19401046). We are thankful to Gökcan Dairy Cattle Farm.

\section{References}

Asher A, Sbabta A, Brosh A, Eitam H, Agmon R, Cohen-Zinder M, Zubidat A E \& Haim A (2015). Chrona-functional milk": The difference between melatonin concentration in night-milk versus day-milk under different illumination conditions. Chronabiol International 32: 14091416 https://doi.org/10.3109/07420528.2015.1102149

Atasoy Ö B \& Erbaş O (2017). Physiological effects of melatonin hormone. İstanbul Bilim Üniversitesi Florence Nightingale Tıp Dergisi 3(1): 52-62 doi: 10.5606/fng.btd.2017.011

Bae S M, Jeong J, Jeon H J, Bang Y R \& Yoon I Y (2016). Effects of melatonin-rich milk on mild insomnia symptoms. Sleep Medicine Research 7(2): 60-67 https://doi.org/10.17241/smr.2016.00108

Balch P A (2010). Health and Fitness, boks.google.com.tr/books. ISBN=1583332367, Access Date: 6.9.2010

Boztepe S (2019). Miracle in the Pineal: Melatonin and its use in animal husbandry. Journal of Konya Commodity Exchange, 13(38): 61-63

Gupta B B P \& Spessert R (2007). Regulation of Melatonin Synthesis: Animal versus Human Studies, In: S R Pandi-Perumal \& D P Cardinali (Eds.) Melatonin: From molecules to Terapy pp. 117-134

Jainudeen M R, Wahid H \& Hafez E S E (2000). Sheep and Goats. In: E S E Hafez \& B Hafez (Eds.), Reproduction in Farm Animals pp. 172179

Jimenez A, Andres S \& Sanchez J (2009). Effect of melatonin implants on somatic cell counts in dairy goats, Small Ruminant Research 84: 116-120. doi:10.1016/j.smallrumres.2009.06.015

Karasek M \& Winczyk K (2006). Melatonin in humans. Journal of Physiology and Pharmacology 57(5): 19-39

Kesici T \& Kocabaş Z (2007). Biostatistics. Ankara University Faculty of Pharmacy Biostatistics Publication No: 94 (Second Edition), Ankara University Printing Office, Ankara 
Konturek S J, Konturek P C, Brzozowski T \& Bubenik G A (2007). Role of melatonin in upper gastrointestinal tract. Journal of physiology and pharmacology 58(6): 23-52

Liu T \& Borjigin J (2006). Relationship between nocturnal serotonin surge and melatonin onset in rodent pineal gland, Journal of Circadian Rythms 4:12 doi: 10.1186/1740-3391-4-12

Minitab (2010). Minitab 16 statistical software. URL: [Computer software]. State College, PA: Minitab, Inc. (www. minitab.com)

Mullins K J (2010). Night time milking produces milk with extra melatonin, digitaljournal.com/article/297161 (SEP 7, 2010), Access Date: 16.09.2010

Ölmez E, Şahna E, Ağkadir M \& Acet A (2010). Melatonin: Retiring at the age of 80? Journal of Inonu University Medical Faculty 7(2): 177187

Özçelik F, Erdem M, Bolu A \& Gülsün M (2013). Melatonin: General Features and its Role in Psychiatric Disorders. Current Approaches in Psychiatry 5(2): 179-203 doi:10.5455/cap.20130512

Romanini E B, Volpato A M, dos Santos J S, de Santana, E H W, de Souza C H B \& Ludovico A (2019). Melatonin concentration in cow's milk and sources of its variation. Journal of Applied Animal Research 47(1): 140-145. https://doi.org/10.1080/09712119.2019.1583570

Salt A, Çenesiz M \& Çenesiz S (2017). Melatonin, its effects and uses. Journal of Etlik Veterinary Microbiology 28(1): 7-12

Singh R \& Rao P S (2016). "High Melatonin Milk" - Milk with Intrinsic Health Benefit. Research \& Reviews: Journal of Dairy Science and Technology 5(1): 13-16

Srinivasan V, Pandi-Perumal S R, Brown G M, Cardinali D P, Spence D W \& Hardeland R (2011). Melatonin: Apleiotropic, orchestrating regulator molecule. Progress in Neurobiology 93: 350-384

Valtonen M, Niskanen L, Kangas A P \& Koskinen T (2005). Effect of melatonin-rich night-time milk on sleep and activity in elderly institutionalized subjects. Nordic Journal of Psychiatry 59(3): 217-221 https://doi.org/10.1080/08039480510023034

Yazıcı C \& Köse K (2004). Melatonin: The antioxidant power of darkness, Erciyes University Journal of Health Sciences 13(2): 56-65

C 2021 by the authors. Licensee Ankara University, Faculty of Agriculture, Ankara, Turkey. This article is an open access article distributed under the terms and conditions of the Creative Commons Attribution (CC BY) license (http://creativecommons.org/licenses/by/4.0/). 